\title{
Palladium Complex Containing Curcumin as Ligand: Thermal and Spectral Characterization
}

\author{
Mônica Aparecida Rodrigues, Jehorgyelly Nunes Fernandes, Reinaldo Ruggiero, and Wendell Guerra* \\ Chemistry Institute, Federal University of Uberlândia, João Naves de Ávila Avenue, 2121, Campus Santa Mônica, Uberlândia - MG, \\ 38.400-902, Brazil \\ wg@iqufu.ufu.br
}

\begin{abstract}
Reaction of curcumin with $\mathrm{K}_{2} \mathrm{PdCl}_{4}$ at $\mathrm{pH} 9.0\left(60^{\circ} \mathrm{C}\right)$ produces a neutral complex of palladium containing curcumin as ligand. The compound was characterized by conductivity measurements, elemental analysis, infrared and UV-visible electronic spectroscopy and thermogravimetric analysis (TGA/DTA). The spectroscopic techniques show that the ligand is coordinated to palladium(II) via $\beta$-diketone group. Thermal studies supported the chemical formulation of this complex and showed that the same has general structure $\left[\mathrm{Pd}(\mathrm{Cur}-\mathrm{H})_{2}\right] \cdot 2 \mathrm{H}_{2} \mathrm{O}$.
\end{abstract}

Keywords Palladium Complexes, Curcumin, Metal Dye Complexes

\section{Introduction}

Curcumin, a component of Curcuma Longa rhizomes is a phenolic compound that has a series of beneficial properties such as antitumor activity, anti-inflammatory and antioxidant[1-5]. This series of beneficial properties has caused an explosive growth in the interest of the academic community to understand how this compound acts, for example, in preventing cancer. Thus, a series of studies are ongoing, including phase of clinical trials, against a great number of diseases such as cancer, psoriasis and Alzheimer's disease[5-9].

In the biological conditions, curcumin can coordinate with metallic ions through the acetylacetonate group. In almost all work reported in literature, complexes of curcumin formed is of the type $\mathrm{ML}_{2}$ where the metallic ion has electrical charge +2 , and complex of the type $\mathrm{ML}_{3}$, when the ion metallic has electrical charge $+3[10-15]$. Many these complexes were evaluated for various biological activities and very interesting results have been reported[15-21]. An interesting example refers to a palladium complex containing bypyridine and curcumin, that induces both cell growth inhibition as apoptosis of human prostate cancer cells ( $\mathrm{LnCaP}, \mathrm{PC} 3$, and DU145), through the production of ROS and JNK phosphorylation associated with GSTp1 down regulation[22]. Curiously, palladium complex containing only the curcumin has not been studied and, it would be interesting, since this neutral compound can be more active and useful.

These observations encouraged us to further

* Corresponding author:

wg@iqufu.ufu.br (Wendell Guerra)

Published online at http://journal.sapub.org/chemistry

Copyright (C) 2012 Scientific \& Academic Publishing. All Rights Reserved investigations. Thus, in the present study; we report the thermal and spectral characterization of complex of palladium containing curcumin. Subsequently, their biological properties will be evaluated.

\section{Results \& Discussion}

A palladium complex containing curcumin as ligand was synthesized using a methodology different of the described in literature for $[\mathrm{Pd}(\mathrm{Curc}-\mathrm{H}) 2] 4 \mathrm{Ace}[23]$. The structure this compound was proposed considering only elemental analysis data. In this work, the complex containing curcumin, $\left[\mathrm{Pd}(\mathrm{Curc}-\mathrm{H})_{2}\right] \cdot 2 \mathrm{H}_{2} \mathrm{O}$, was characterized by elemental analysis, conductivity measurements, IR, UV-Vis and thermogravimetric analysis. The chemical structure of the ligand and their palladium complex are presented in Figure 1.

The results of the elemental analyses $(\mathrm{C}, \mathrm{H}, \mathrm{N}$ and $\mathrm{Pd})$ are in accordance with the proposed structure.

The molar conductance measurement of the palladium complex was performed in DMF solution (with a concentration of $1 \times 10^{-3} \mathrm{M}$ ) at room temperature. The value obtained $\left(4.02 \mathrm{~S} \cdot \mathrm{cm}^{2} \cdot \mathrm{mol}^{-1}\right)$ indicates that the compound is nonelectrolytes[24].

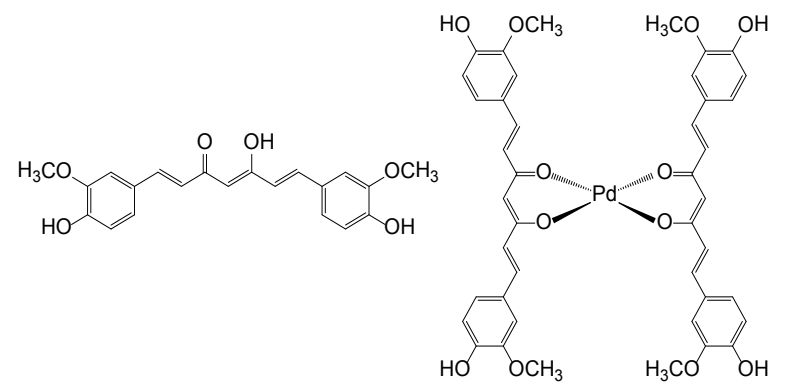

Figure 1. Structure of curcumin and of palladium complex obtained 


\section{IR spectra}

The IR spectrum of the free ligand (Curc-H) was performed just for comparison to the corresponding complex isolated. The characteristic absorptions in the 3500 to 2800 $\mathrm{cm}^{-1}$ region were observed, corresponding to $\mathrm{vOH}, \mathrm{vCH}$ (aromatic) and $v \mathrm{CH}$. An absorption at $1628 \mathrm{~cm}^{-1}$ corresponding to $v \mathrm{C}=\mathrm{O}$ group.

In the IR spectrum of complex, the peak due $v \mathrm{C}=\mathrm{O}$ was found to be shifted towards lower wavenumbers. Thus, it is possible to ascertain the coordination of the oxigen of the $\mathrm{C}=\mathrm{O}$ group to metal. Was also observed that the complex had no broad band in the $2800-3400 \mathrm{~cm}^{-1}$ range, related to the stretching of intramolecular $\mathrm{H}$ in the enol function, which indicates that the carbonyl group of the ligand is really coordinated to $\mathrm{Pd}(\mathrm{II})$.

The remaining characteristic bands and signals of free ligand were not affected by metal coordination and these results suggest that the ligand is bonded to the metallic ion via $\beta$-diketone group group.

\section{Electronic spectra}

In order to confirm the metal binding to ligand, we have analyzed the spectra in the UV-visible regions in acetonitrile (Figure 2).

The UV-visible absorption spectrum of the curcumin $\left(1 \times 10^{-3} \mathrm{molL}^{-1}\right)$ displays two bands centered at 261 and 417 $\mathrm{nm}$. On the other hand, the spectrum of the complex showed four peaks in the ultraviolet region $(262,406,430$, and 454 $\mathrm{nm}$ ). The observation that the main band of the ligand (417 $\mathrm{nm}, \pi-\pi^{*}$ transition) have shifted to slightly higher energy, is an indicative of involvement of the carbonyl group of curcumin in metal complexation[21]. The splitting observed in the spectrum of the complex too is consistent with the coordination of the ligand to metal.

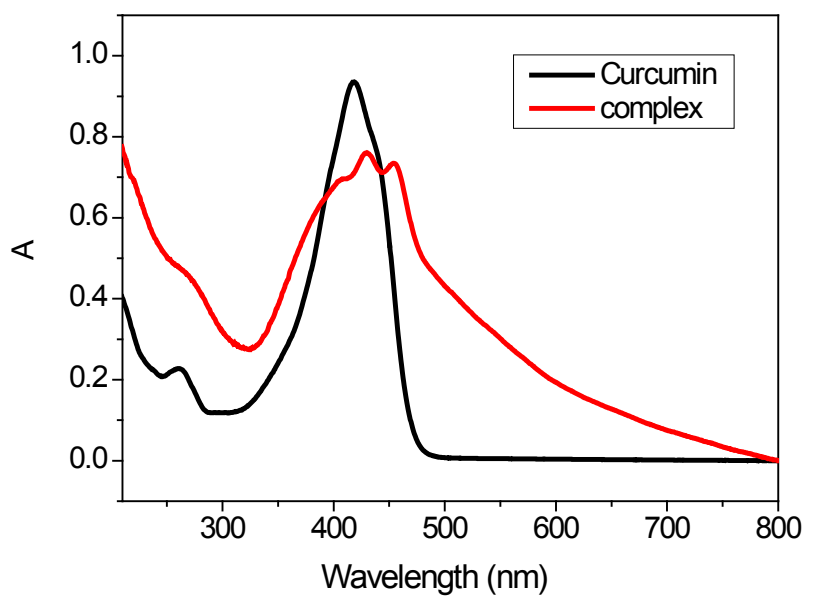

Figure 2. Electronic spectrum of the curcumin and its palladium complex (acetonitrile, $1.0 \times 10^{-5} \mathrm{~mol} \mathrm{~L}^{-1}$ )

\section{Thermal analyses}

The thermal stability of the curcumin complex was followed in the temperature range between $25-850^{\circ} \mathrm{C}$ in $\mathrm{N}_{2}$ atmosphere. The weight loss of the prepared compound displays a good agreement with the stoichiometry. The TG/DTA curve for the complex $\left[\mathrm{Pd}(\mathrm{Curc}-\mathrm{H})_{2}\right] \cdot 2 \mathrm{H}_{2} \mathrm{O}$ (Figure 3 ) shows a series of events weight loss. The first one, in the range of 50 to $110^{\circ} \mathrm{C}$ (endothermic event), corresponds to the loss of two water molecules (calculated: 4.10\%; found: $4.26 \%$ ). Events at $150-810^{\circ} \mathrm{C}$ range are attributed to ligand thermal decomposition. At $900^{\circ} \mathrm{C}$, there is a residue that was identified by X-ray diffractometry as elemental palladium, ICDD data bank (International Center for Diffraction Data) number 5-681. The percentage of palladium fits well with the proposed formula. \% Pd calcd. for complex: 12.13; Found: 12.40 .

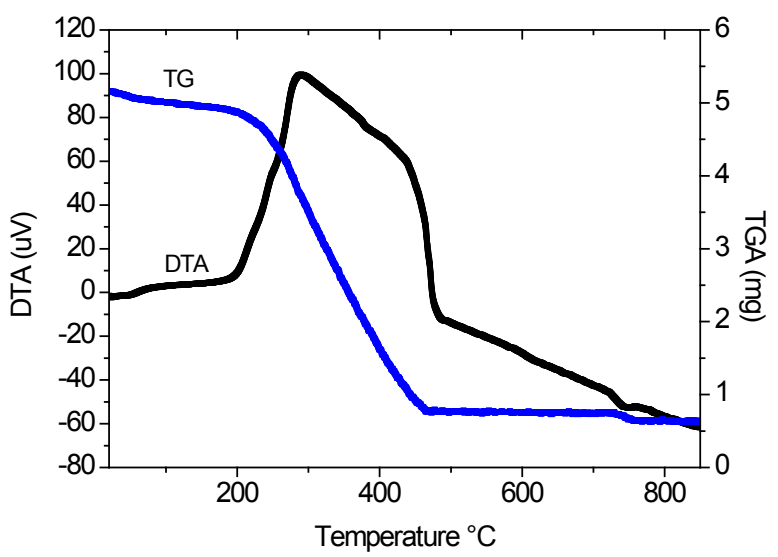

Figure 3. TGA/DTA curves for palladium complex

\section{Conclusions}

A complex of palladium was isolated with curcumin and characterized by spectroscopic and thermals techniques. The results show that the palladium ion bind to curcumin occurs via the oxygen atoms of the $\beta$-diketone group. Thermal studies supported the chemical formulation of this complex and showed that the same decompose in various steps. Considering the structure of compound obtained, the investigation of its biological properties is desirable to determine their possible utility as drug, thus, later their properties of cytotoxity and antioxidant will be performed in our laboratory.

\section{Experimental}

\section{Starting materials}

The reagents are commercially available (Aldrich). All other reagents chemicals were of analytical grade, purchased from different sources, and used without further purification.

Physical measurements

Conductivity studies were carried out with a Digimed DM 31 conductivity meter using a cell of constant $1.00 \mathrm{~cm}^{-1}$, spectroscopic grade dimethylformamide (Merck) $\left(\Lambda_{\mathrm{M}}=1.20\right.$ $\left.\mu \mathrm{s} / \mathrm{cm}^{-1}\right)$ and tetraethylammonium bromide $\left(\Lambda_{\mathrm{M}}=78.39\right.$ $\left.\mu \mathrm{s} / \mathrm{cm}^{-1}\right)$ as a standard.

Elemental analyses (C, $\mathrm{H}$ and $\mathrm{N}$ ) were performed using a 
Perkin-Elmer 2400 CHN Elemental Analyser. Palladium content was determined by atomic absorption on a Hitachi spectrophotometer model 8200.

IR spectra were registered in $\mathrm{KBr}$ pellets on a Shimadzu FTIR-Irprestige-21 spectrometer.

Spectrophotometer UV-2501 PC Shimadzu was used for $\mathrm{UV}$ and visible absorption measurements.

Thermogravimetric analyses (TG/DTA) were obtained on a TGA-50 Shimadzu, using $6.0 \mathrm{mg}$ samples packed in aluminum crucible. Samples were heated at $10^{\circ} \mathrm{C} / \mathrm{min}$ from room temperature to $900^{\circ} \mathrm{C}$, in a dynamic nitrogen atmosphere (flow rate $=200 \mathrm{~mL} / \mathrm{min}$ ). The residue was analyzed by X-ray diffratometry on a Siemens D5000 apparatus using a copper tube and radiation $\mathrm{Cu} \mathrm{Ka}=1.54178 \AA$, with $2 \theta$ angle varying from 0 to $90^{\circ}$.

\section{Synthesis of complex}

$0.163 \mathrm{~g}$ of $\mathrm{K}_{2} \mathrm{PdCl}_{4}(0.5 \mathrm{mmol})$ previously dissolved in water was added to $5 \mathrm{~mL}$ of a methanolic solution of curcumin $(1.0 \mathrm{mmol})$ at $60^{\circ} \mathrm{C}$. After $2 \mathrm{~h}$, the $\mathrm{pH}$ was then adjusted to 9.0 by adding triethylamine dropwise and the mixture was stirred for $24 \mathrm{~h}$. The solid formed was separated by filtration, washed with methanol and water, and dried under vacuum.

$$
\text { Complex - }\left[\mathrm{Pd}(\mathrm{Curc}-\mathrm{H})_{2}\right] .2 \mathrm{H}_{2} \mathrm{O}
$$

Yield: $65 \%$. Color: Brown. Anal. Calcd. for $\left[\mathrm{Pd}\left(\mathrm{C}_{21} \mathrm{H}_{19} \mathrm{O}_{6}\right)_{2}\right] 2 \mathrm{H}_{2} \mathrm{O}: \mathrm{C}, 57.45 ; \mathrm{H}, 4.78 \% ; \mathrm{N}, 0 \% ; \mathrm{Pd}$, 12.13 Found: C, 57.31; H, $4.56 \%$; N, 0\%; Pd, 12.06. IR spectra in $\mathrm{KBr}, v\left(\mathrm{~cm}^{-1}\right): 3500,2931,2840,1623,1597,1511$, 1460, 1427, 1391, 1275, 1214, 1166, 1125, 1030, 971, 845, $820,850,724,613,564$.

\section{ACKNOWLEDGEMENTS}

This work was supported by grants of CNPq (Conselho Nacional de Desenvolvimento Científico e Tecnológico, Brazil) and FAPEMIG (Fundação de Amparo à Pesquisa de Minas Gerais, Brazil).

\section{REFERENCES}

[1] Toennesen, H. H.; Karlsen, J.; J. Chromatogr. 259, 367, (1983).

[2] Aggarwal, B. B.; Harikumar, K. B. Inter. J. Biochem. Cell Biol. 41, 40 (2009).

[3] Govindarajan, V.S.; Crit. Rev. Food Sci. 12, 199, (1979).

[4] Majeed, M.; Badmaev, V.; Shimakumar, U.; Rajendran, R.; Curcuminoids: Antioxidant Phytonutrients, Nutriscience Publishers Inc., Piscataway, 1990.
[5] Basnet, P.; Skalko-Basnet, N. Molecules, 16, 4567 (2011).

[6] Pan, M. H.; Huang, T. M.; Lin, J. K.; Drug Metab. Dispos. 27, 486, (1999).

[7] Osawa, T.; Sugiyama, Y.; Inayoshi, M.; Kawakishi, S.; Biosci. Biotechnol. Biochem. 59, 1609, (1995).

[8] Sugiyama, Y.; Kawakishi, S.; Osawa, T.; Biochem. Pharmacol. 52, 519, (1996).

[9] Nakamura,Y.; Ohto, A.; Murakami, T.; Osawa, H.; Ohigashi, J. P. N.;. J. Cancer Res. 89, 361, (1998).

[10] Kim, J. M.; Araki, S.; Kim, D. J.; Park, C. B.; Takasuka, N.; Baba-Toriyama, H.; Ota, T.; Nir, Z.; Khachika, F.; Shimidzu, N.; Tanaka, Y.; Ozawa, T.; Uraji, T.; Murakoshi, M.; Nishino, H.; Tsuda, H.; Carcinogenesis 19, 81, (1998).

[11] Mohammadi, k.; Thompson, k. H.; Patrick, B. O.; Storr, T.; Martins, C.; Polishchuk, E.; Yuen, V. G.; McNeill, J. H.; Orvig, C.; J. Inorg. Biochem. 99, 2217 (2005).

[12] Thompson, K. H.; Bohmerle, K.; Polishehuk, E.; Martins, C.; ToleiKij, P.; Tse, J.; Yuen, V.; McNeill, J. H.; Orvig, C. J. Inorg. Biuochem. 98, 2063 (2004).

[13] Ahsan, H.; Hadi, SM.; Cancer Lett. 124, 23 (1998)

[14] John,V. D.; Krishnankutty, K.; Transition Metal Chem. 30, 229 (2005).

[15] Borsari, M.; Ferrari, E.; Grandi, R.; Saladini, M.; Inorg. Chim. Acta 328, 61 (2002).

[16] Vajragupta, O.; Boonchoong, P.;Berliner, L. J.; Free Radic. Res. 38, 303 (2004).

[17] Hatcher, H.; Planalp, R.; Cho, J.; Tortia, F. M.; Torti, S.V.; Cell. Mol. Life Sci. 65, 1631, (2008).

[18] Barik, A.; Mishra, B.; Kunwar, A.; Kadam, R. M.; Shen, L.; Dutta, S.; Padhye, S.; Satpati, A. K.; Hong-Yu Zhang, Priyadarsini K. I.; Europ. J. of Med. Chem. 42, 431, (2007).

[19] Sharma, K. K.; Chandra, S.; Basu, D. K.; Inorg. Chim. Acta 135, 47, (1987).

[20] Krishnankutty, K.; Venugopal, P.; Synth. React. Inorg. Met. Org. Chem. 28, 1313, (1998).

[21] Song Yu-Min, Xu Jun-Peng, Ding L.; Hou Q.; Liu J. W.; Zhu Zao-Long J. Inorg. Biochem. 103, 396, (2009).

[22] Valentini, A.; Conforti, F.; Crispini,A.; De Martino, A.; Condello,R.; Stellitano, C.; Rotilio, G.; Ghedini, M.; Federici, G.; Bernardini, S.; Pucci, D.; J. Med. Chem. 2009, 52, 484-491.

[23] Kuhlwein, F.; Polborn, K.; Beck, W.; Z. anorg. allg. Chem. $623,1211,(1997)$

[24] Geary, W.; J. Coord. Chem. Rev. 7, 81, (1971) 